\title{
オンライン分析計によるウェットエンド管理とその制御法*
}

\author{
ネレスオートメーション株式会社 大木 悟, ○坂田 秀赛
}

\section{Wet End Management Based on On-Line Measurements and Control Solutions}

\section{Satoru Ooki and OHidemi Sakata}

Neles Automation Co. Ltd.

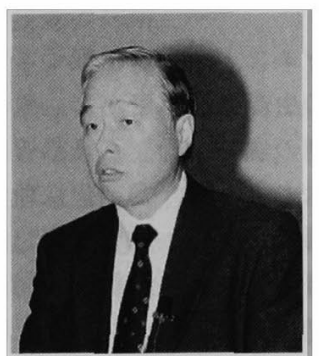

坂田秀実

In order to manage the wet end chemistry on paper machines, our goal is to control sub-processes through which we can influence the entire wet end operation with maximum effect. The most important sub-processes are : consistency. ash, and chemistry.

The management of these three main groups is based on on-line measurements and automatic control.

This paper presents a new wet end management platform, a new analyzer. This new analyzer utilizes a modular structure and modern software. It is part of anew paper machine concept.

The controls of this concept are feedback and feedforward solutions that control retention, consistencies, ash, and charge, resulting in a more stable wet end $(30-80 \%)$, more uniform paper, and better runnability.

Keywords : Paper machine. Wet End. Automatic control, Retention. Consistency, Cationic demand 分類： $\mathrm{M}_{1}$ 抄紙・抄紙機一般, $\mathrm{M}_{2}$ マシンチェストおよび白水回収, $\mathrm{V}_{2}$ 紙パルプ工程制御システム

1.はじめに

ウエットエンド制御は非常に重要で，さらには以下 の要因および傾向から, 今後, 益々重要性は增してき ている。

・ペーパーマシンの開発（マルチレイヤー, ディル ーションヘッドポックス, ギャップフォーマー)

・活性フォーミングセクションの開発の必要性

・マシンスピードの増加一抄紙機の生産能力を引き 上げる際のもっとも重要なファクター

*平成 11 年度年次大会講演（講演 No.C 14）
- 生産紙の坪量が軽くなり続けていると同時に灰分 の增加

・より高いプロセス温度 $\left(60^{\circ} \mathrm{C}\right.$ 又はそれ以上)

・新しいコーティングと印刷プロセス

・将来的には䋳維原料の多様化と, 使用される原材 料の平均化した品質の低下

・添加物と補助の各種薬品の使用料增加

・ますます增える薬品量とプロセスの最適化と新し い操業方法, 最も基本となる原材料の水の消量は 限られており，同時に水の品質も悪化してきてい る。

・アルカリ紙の生産プロセスが徐々に増加 
これらすべての要因により，プロセスが益々瀻細で 変動しやすくなっていることを意味する。より効率的 に紙を作り，同時に製品の品質を改善するという目標 をあげるなら, ウエットエンド制御に着目して改善す ることで, 最低コストで最大のメリットが得られる。

最先端のシステムは信頼できる連続測定であり, 効 率的な紙の生産は, 信頼できる精度の有る連続測定を 基にした，最新の自動制御を利用している。

\section{2. ウエットエンドの安定性}

ウエットエンドを安定に保つことは, 効果的及び経 済的な紙の生産の基本である。ウエットエンドの濃度 および薬片の変動は操業と紙品質に問題をもたらす。

図 1 に示すように, 安定化は新しい効果的で最適な 薬品の利用と同時に, 重要な測定値を基にしたプロ七 ス手法, 自動化技術と最新の制御システムによって達 成できる。ワンパスリテンションはショートサーキュ レーションにおける濃度から計算される。このように, 濃度はショートサーキュレーションの安定性の指標と なる。

また，濃度はリテンションを通してワイヤーセクシ ヨンの操業性を示し, そして生産される紙料の品質に 密接な相関が見られる。紙料の調整及びショートサー キュレーションに扔ける濃度変動は直接ドライエンド におけるマシン方向 (MD) とクロス方向 (CD) の 秖品質の変動と関連がある。このようにウエットエン ド濃度の測定と安定化は非常に重要である (図 2)。

クロス方向の $2 \sigma$ と稀釈水濃度と坪量の標準偏差に は明らかな相関が見られる。紙の灰分は填料とコーテ インク用のペースト顔料からなり, 両者とも保持力は 強くなく，紙の灰分コントロールは抄紙機の製品に対 し非常に重要な要因である。紙料のクロス方向と, マ シン方向の灰分の分布むらは, 抄紙, 仕上げ及び印刷 上での操業に問題をもたらし，さらには紙品質を悪化 させる。マシン方向の灰分変動は新たな填料供給、リ

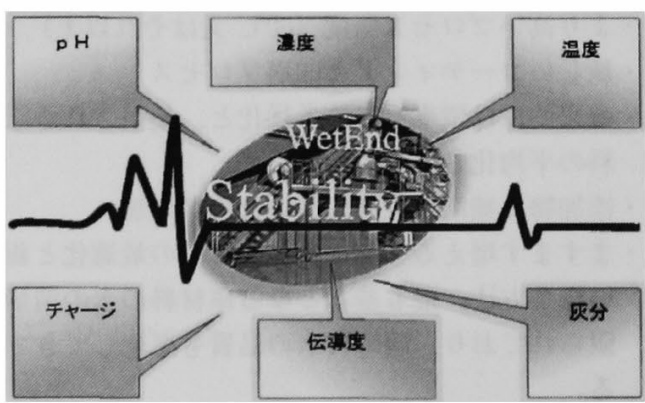

図 1 ウェットエンドの安定化の主な要因
テンション及びヘッドボックスに入る完成紙料の変動 によって引き起こされる。

\section{1 ウエットエンド管理（WEM）のための 制御コンセプト}

WEM コンセプトの原理は，ショートサーキュレー ションの操業に影響を与える重要なサブプロセスを制 御することである。実際のウエットエンドの管理は 3 種類の主なグループつまり濃度, 灰分と薬品に含まれ る，いくつかのサブプロセスに分類できる。これら主 要なグループの管理は, オンライン測定と自動制御が 基本となる。全ての主グループは，お互いに強い関連 があるため，包括的なアブローチが必要である。例え ばチャージは，全濃度及び灰分りテンションの両方に 影響を与えるが，同程度ではない。もう一つの重要な ことは，もっとも応答性のよい制御が可能となるよう フィードバックとフィードフォワード制御とを組み合 わせることである。この動的な前方向の予測的な制御 アプローチは従来の訂正動作を行う制御からは明らか に一歩進んだ位置にある。

この $\mathrm{pH}$ と温度測定は基本の制御項目で十分に制御 されているという前提となっている。ショートサーキ ュレーションの $\mathrm{pH}$ と温度は主なモニター項目の一つ で, 十分にチューニングされていることが必要である。 伝導度測定もまたショートサーキュレーションの状態
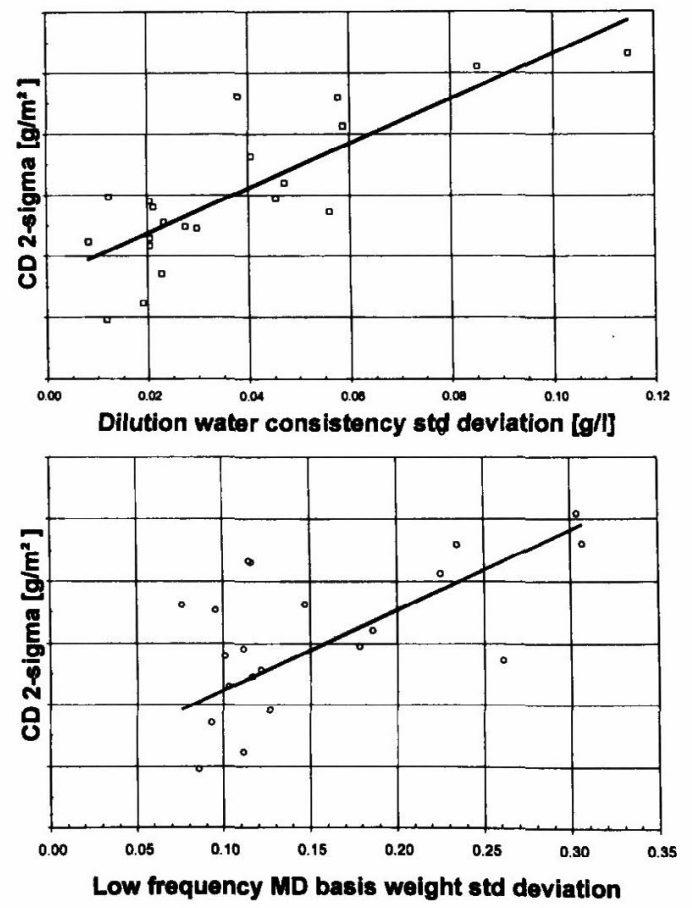

図 2 坪量と希釈水濃度およびマシン方向の関係 
を表す指標の一つである。

白水の全濃度は自動的なリテンション刘の流量で制 御する。これはファーストパスリテンションの制御と 安定化にもっとも効果的な方法である。この方法は, さらにウエットエンド全体の濃度を安定化させ, マシ ン方向とクロス方向の紙品質を大幅に改善する。この ようにリテンション制御はチャージ制御と並んで重要 な制御の 1 項目である。チャージは, 凝固剤流量を自 動的に変化させて制御される。これによって完成紙料 と，他の薬剤を理想的に利用できるように，ウエット エンドの化学的特性が安定化される。

紙切れ時のヘッドボックス灰分濃度制御は紙切れ中 のウエットエンドを安定した状態に保つために必要で ある。この制御は紙料の通しを容易にし，紙切れ後の 紙の灰分を目標值に維持する。フィードフォワードの 坪量制御と高漕度紙料の灰分制御は予測制御である。

ドライエンドによる制御ではできない, ウエットエン ドに入ってくる濃度と灰分量の外乱を防ぐことができ る。このことにより, 操業性と紙品質の改善をできる。

\section{2 測 定}

WEM コンセプトに必要とされる精度があり，信頼 できる連続湘定が既に利用可能となっている。制御の 発展の中で, 連続測定值は抄紙機のウエットエンドの 強力な品質管理システムであり, 紙の生産システムの 自動化を開く可能性を持ったツールである。

新しいウエットエンド測定のプラットフォームとな
る第一の構成要素は全濃度, 灰分濃度, それぞれのリ テンション, フロキュレーションの程度, 基本的な化 学的物性值 ( $\mathrm{pH}$, 伝導度と温度) などである。

新しい, 分析計の開発の指針は, つぎの通り。

・モデュール化と拡張性

・組み込みアプリケーション

・信頼性とメインテナンス機能の改善

・現代的で柔軟なユーザーインターフェースとリモ ートオペレーション

・新しい紙の生産技術の採用

新型分析計のデザインはバルメットのオプティコン セブトに密接にのっとっている。分析計は，抄紙機の オートメーションにも組み込まれている。フィールド の環境下での操作性が全面的に信頼できることを意味 しており，プロセスコントロールシステムのみならず， 同時に抄紙のドライエンドの品質管理にすら統合する ことができる。このようにドライエンドの制御とウエ ットエンドの測定及び制御が連携しているのは他に類 がない。

新型分析計は，モデュール構造で仕様にあわせて装 備することができる。必要に応じて，いくつでも分析 計を相互に連結でき，非常にすばらしい拡張性のある システムを構築できる。測定は,オンラインで連続的 に行われており，また一台の分析計は 5 個所までのサ ンプリングラインに接続できる。

分析計のユーザーインターフェースはウインドウベ

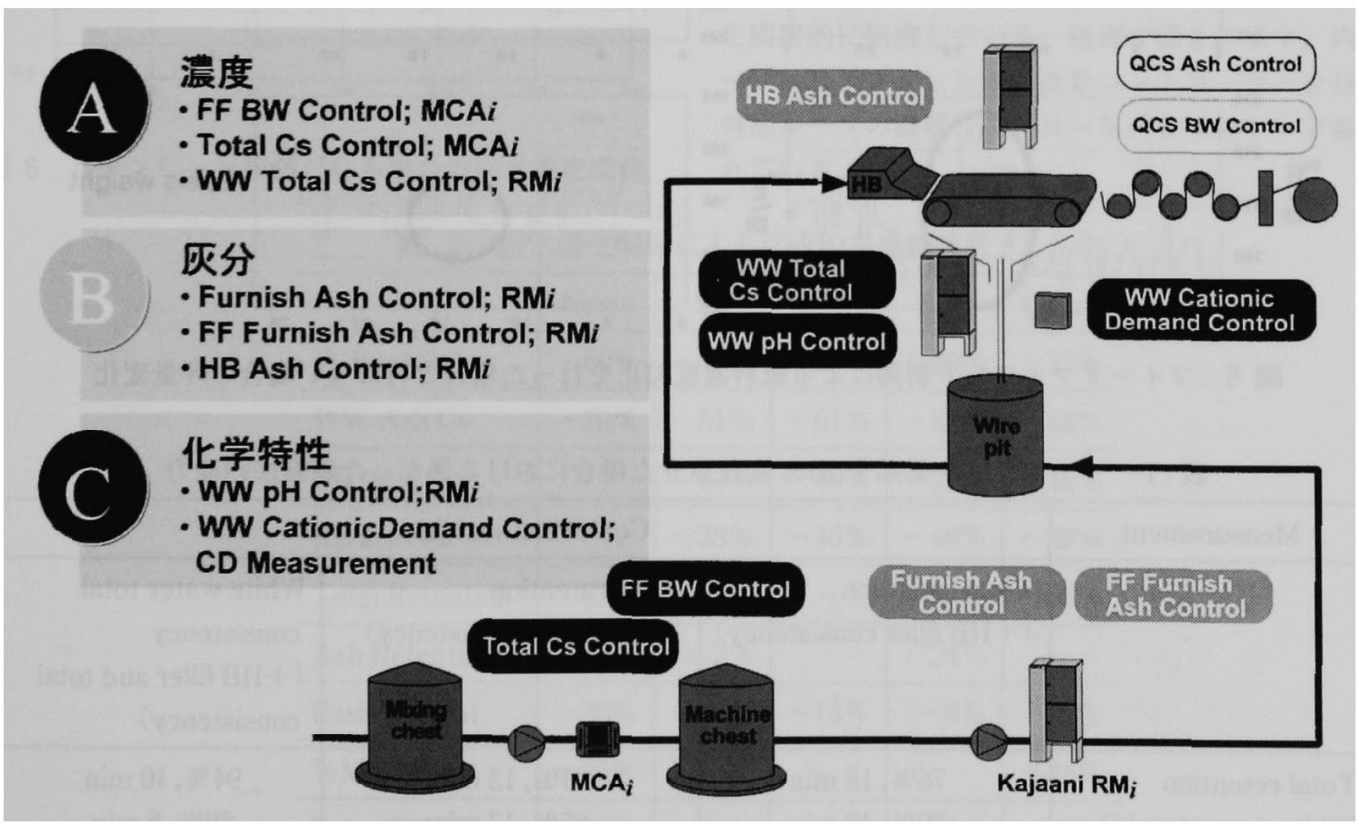

図 3 ウェットエンド管理の概念 


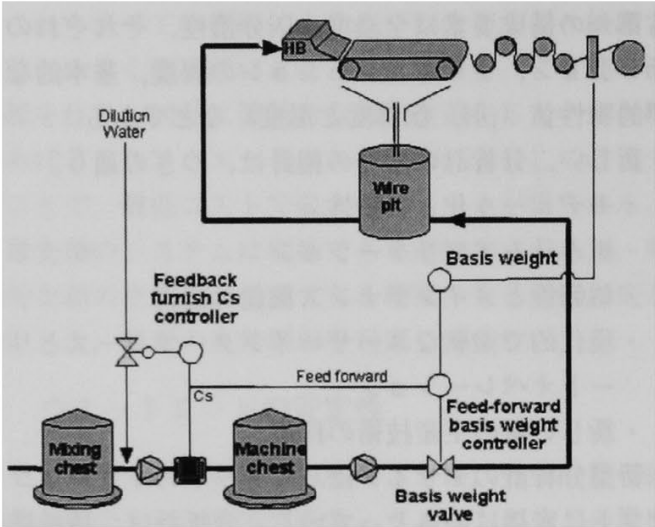

図 4 坪量フィードフォワード制御
ースのPC,または分析計に值接接続して利用するノ 一ト型 PCのどちらかとなる。モデムを利用して遠隔 利用するシステムも可能で, 操作条件の設定, 自己診 断, データ収集と分析が, 通信ラインを使って装置の 場所にかからわず行うことができる。

\section{3. 濃 度 制 御}

\section{1 高濃度紙料のフィードフォワード制御}

従来の坪量制御は, ドライエンドの坪量測定を使っ た高濃度紙料の流量制御である。測定値とコントロー ル位置との間に遅れがありここ種の坪量制御は, 高 濃度紙料によりもたらされるような, 非常に早い変化 には対処できない。正確な信頼できる濃度測定が, 坪 量制御をかなり改善することができる。濃度測定を基
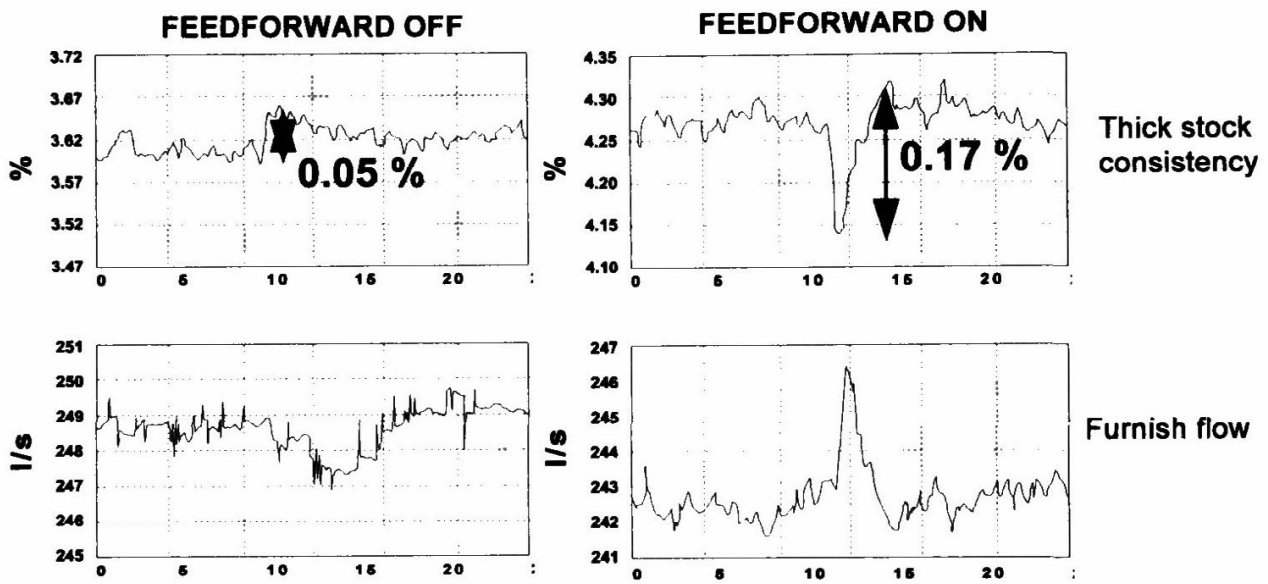

\section{Furnish flow}
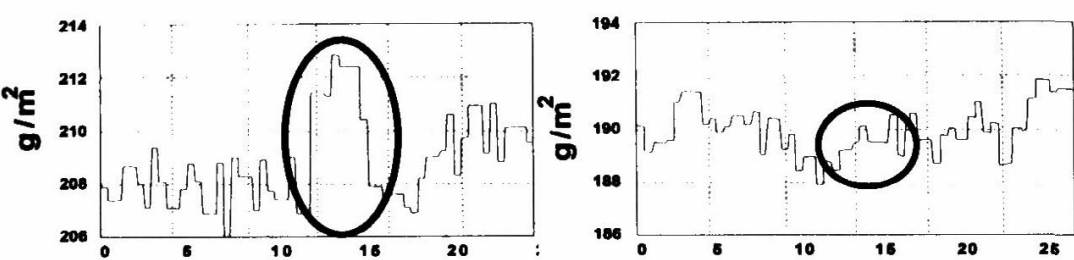

Basis weight

図 5 フィードフォワード制御による紙料濃度補正を行った場合と行わない場合の坪量変化

表 1 リテンション薬品を $20 \%$ 変化させた場合における異なった制御法の能力

\begin{tabular}{l|c|l|l}
\hline \multicolumn{1}{c|}{ Measurement } & \multicolumn{3}{|c}{ Controlled variable } \\
\hline & $\begin{array}{l}\text { Total retention } \\
\text { (+HB filler consistency })\end{array}$ & $\begin{array}{l}\text { Filler retention } \\
(+\mathrm{HB} \text { filler consistency })\end{array}$ & $\begin{array}{l}\text { White water total } \\
\text { consistency } \\
(+\mathrm{HB} \text { filler and total } \\
\text { consistency })\end{array}$ \\
\hline Total retention & $\begin{array}{l}76 \%, 18 \mathrm{~min} \\
79 \%, 19 \mathrm{~min}\end{array}$ & $83 \%, 13 \mathrm{~min}$ & $94 \%, 10 \mathrm{~min}$ \\
White water total Cs & $85 \%, 13 \mathrm{~min}$ & $89 \%, 8 \mathrm{~min}$ \\
\hline
\end{tabular}




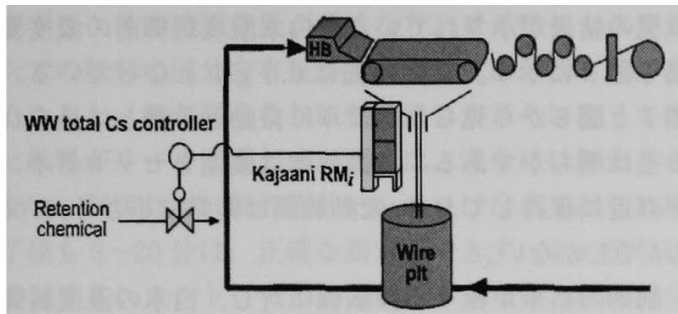

図 6 白水濃度制御システム

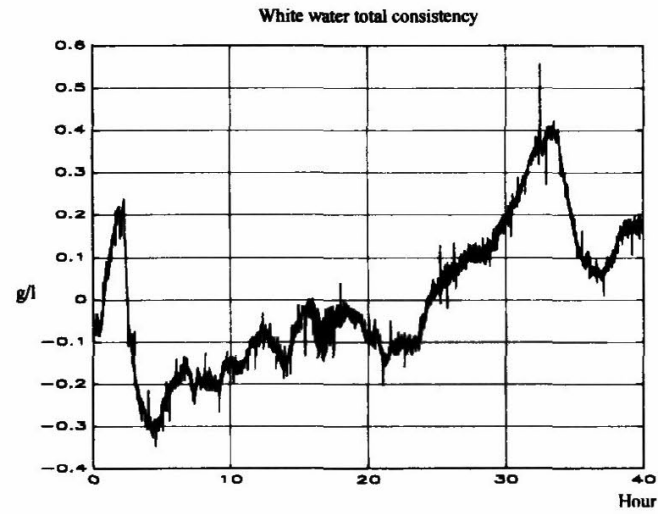

図 7 リテンション制御が無い場合の白水濃度変化

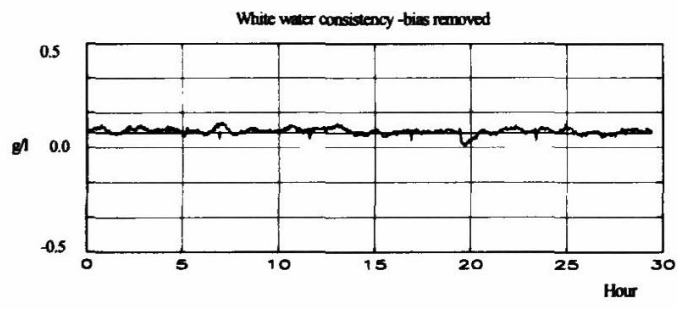

図 8 リテンション制御が有る場合の白水濃度変化
にしたフィードフォワード制御が安定した高濃度紙料 の供給を可能とする。この制御は外乱がヘッドボッ クスに達する前に処置をするため, 結果として紙の品 質と抄紙機の操業性を安定した状態に保つ。

フィードフォワード制御は，従来のすべての紙品質 制御が遅い訂正動作に限定されている領域を予測制御 に迫る制御手法である。この制御法を図 4 に示す。

図 5 に制御の実績を示す。フィードフォワード制御 がオフのときは, まず完成紙料の濃度増加は坪量の上 昇に現われ，その後坪量コントローラーが完成紙料の 流量を徐々に減らし坪量をセットポイント近くに戻し ていく。しかし，フィードフォワード制御が入ると完 成紙料の流れを增やして, 濃度の下降は即座に補正さ れる。

\section{2 白水全濃度制御}

紙にのりにくい原料は，白水に含まれて再びヘッド ボックスに戻ってくる。白水の全濃度の変動を減らす と, ウエットエンド全体の濃度が安定しこのことが 一定したリテンションに反映されてくる。

ワイヤーリテンションをもっとも安定に保つ方法は リテンション剂を利用して, 白水濃度を制御すること である。これは異なるプロジェクトの中の，数種類の 制御テストで実証された。表1（文献 6）に結果を示 す。白水濃度制御により, リテンションと全体のウエ ットエンドがもっとも効率的に安定されたことが示さ れている。

白水の全濃度を制御することによってリテンション を間接的に制御している。原理を図 6 に示す。内部ル ープにリテンション郕の流量コントローラーを持ち, 外部ループの濃度コントローラーとカスケード接続さ れている。

表 2 白水濃度制御による代表的な変動率低下

\begin{tabular}{l|c|c|c|c|c}
\hline & News & SC & LWC & Fine & Board \\
\hline WW total Cs & $-80 \%$ & $-68 \%$ & $-57 \%$ & $-80 \%$ & $-71 \%$ \\
\hline WW Ash Cs & $-70 \%$ & $-51 \%$ & $-61 \%$ & $-67 \%$ & $-44 \%$ \\
\hline HB total Cs & & $-53 \%$ & $-40 \%$ & $-22 \%$ & $-12 \%$ \\
\hline HB Ash Cs & & $-38 \%$ & $-46 \%$ & $-46 \%$ & $-39 \%$ \\
\hline Total Retention & $-67 \%$ & $-44 \%$ & - & $-57 \%$ & $-55 \%$ \\
\hline Ash Retention & - & $-2 \%$ & - & $-24 \%$ & - \\
\hline Basis Weight & $-30 \%$ & $-19 \%$ & $-14 \%$ & $-9 \%$ & $-5 \%$ \\
\hline$\%$ Moisture & $-25 \%$ & & & & $-45 \%$ \\
\hline Paper\%Ash & $-25 \%$ & $-20 \%$ & $-22 \%$ & $-22 \%$ & $-38 \%$ \\
\hline
\end{tabular}


この手法では, 常に必要量のみの薬剤の利用, つま り過小なまたは過大な薬荗投与がないように最適化さ れている。また, リテンション刻の性質や投与システ ム, パルプリファイニング, ブロークの混合や投与等 のプロセスに潜在的に内蔵された問題が現れないよう に小さなうちに押え込む，そして紙となる完成紙料の 前に位置する最後の監視システムであり, 抄紙システ ムの最適調整に利用できる。

以下のグラフに，白水の自動制御の行われている抄

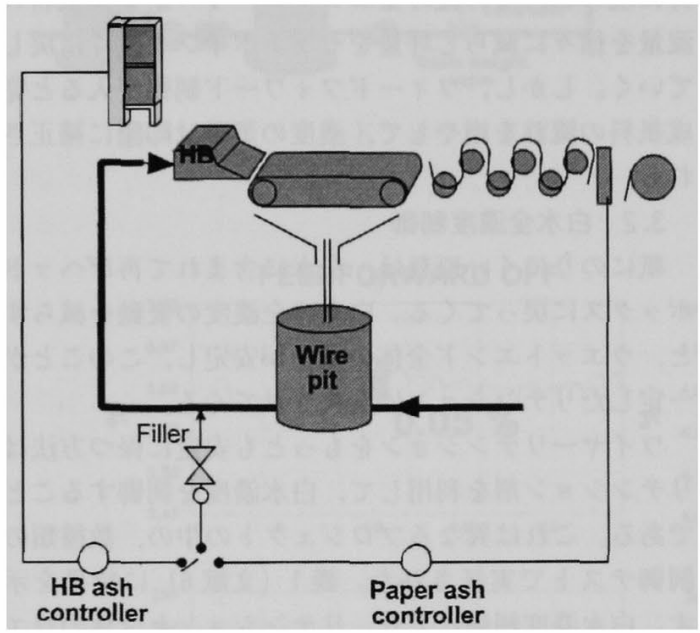

図 9 紙切れ時のヘッドボックスでの灰分濃度制御シ ステム
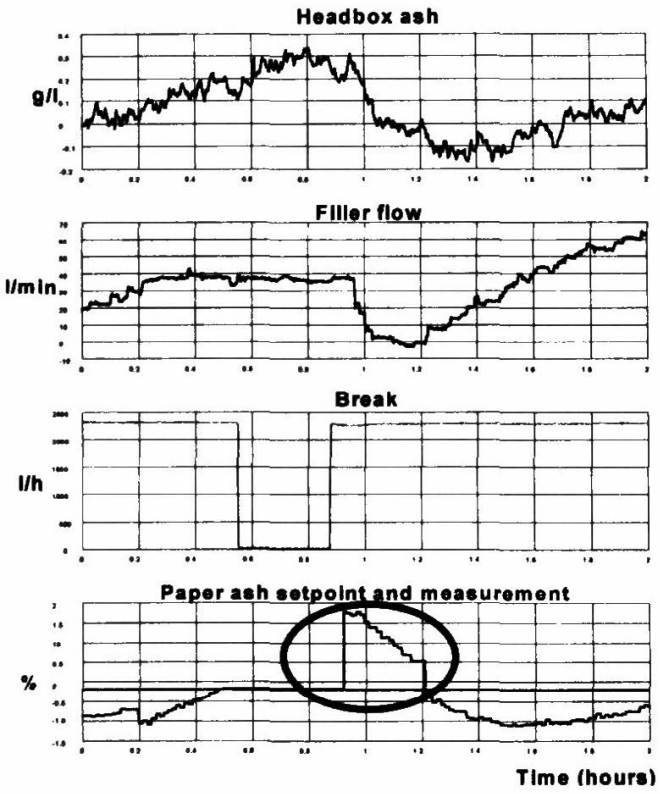

紙機の結果が示されている。白水濃度制御前の濃度変 動を図 7 に示す。変動螌囲は $0.7 \mathrm{~g} / \mathrm{l}$ となっている。 図 7 と図 8 から見られるように自動と手動とに見られ る差は明らかである。自動制御は濃度をセットポイン 卜直近に維持しており,変動範囲は非常に小さく,0.06 $\mathrm{g} / l$ でしかない。

制御の結果が種々の抄紙機に対し，白水の濃度制御 をしているときとしてないときに，同品種の標準偏差 を比較して検討した。表 2 にこの比較結果を示す。表 からわかるように，制御期間中はウエットエンドとド ライエンドの安定性に非常な改善が見られる。これは, よりよい操業が行われていることと紙の品質改善を意 味する。

\section{4. 灰分コントロール}

\section{1 紙切れ時のヘッドボックス灰分濃度制御}

通常の生産時において, 紙の灰分量は抄紙機のドラ イエンドで連続的に測定されており，必要に応じて灰 分流量が補正され，自動制御によって安定に保たれて いる。紙切れの間は，測定が行われず，灰分流量は紙 切れ前の状態に固定される。しかし，紙切れ中にプロ 七スの変化がたまたま起こっても紙料の通しを容易に し，規格外品を最小にするように制御すべきである。 例えば，紙切れ時間が長くなると，ブロークチェスト のレベルが上がり過ぎるためマシーンオペレーターは ブローク流量を多くせざるを得ない。この結果，ヘッ
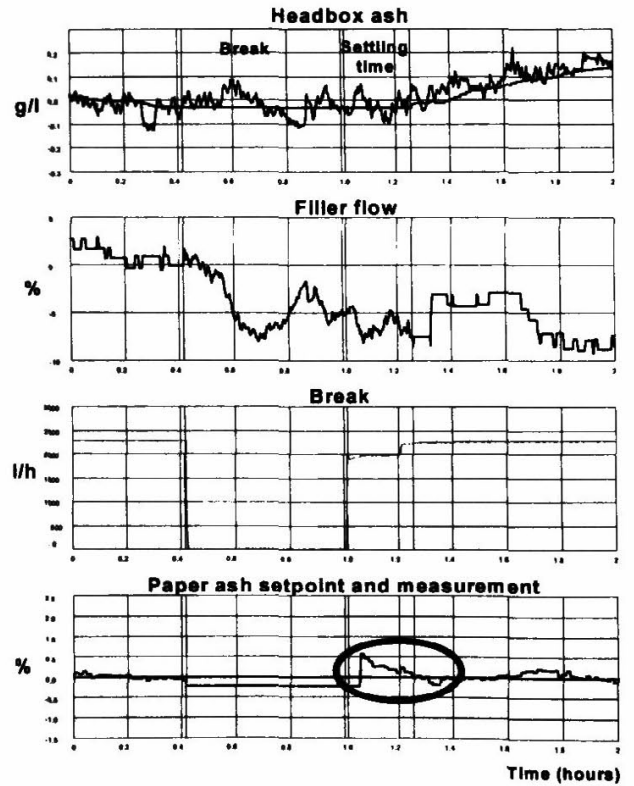

図 10 紙切れ時にヘッドボックス灰分濃度制御を入れた場合と入れない場合の製品での灰分濃度変化 
ドボックスでの灰分量が多くなり，ワイヤーセクショ ンでの紙料の灰分含有量が上昇する。灰分含有量が高 くなると，紙が弱くなり紙料の通しがさらに悪くなる。 紙料がリールに達しても問題は, 完全には解決され ない。紙切れ中, 紙の灰分センサーは冷えて紙切れ終 了後も5〜20 分は, 正確な測定ができず, この信号は オンラインコントロールには使用できない。紙の灰分 量コントロールを再び自動モードにする時に, まず最 初に秖の灰分量をターゲット值に戻す。これは通常填 料流量の急激な変化をもたらし, ウェットエンド濃度 の変動を引き起こし，さらには新たな紙切れに結びっ くことさえある。

これらの問題に対する最善の解決法は, 紙切れ中も ヘッドボックスの灰分浱度を一定に保つことである。 この目的のための制御手法は, ヘッドボックスの灰分 濃度測定を使う。制御システムを図 9 に示す。

図 10 に，紙切れ時灰分制御がどのように作動する かを従来のマシン操業と対比させて示している。従来 の制御手法では，灰分流量は紙切れ前に固定され灰分 制御は作動しない。そこでヘッドボックス灰分濃度と 紙の灰分含有量は增し, 紙切れ後は紙の灰分量は目標 值以上となる。

新しい灰分制御をセットしておくと，紙切れが起こ ると同時にへッドボックス灰分コントローラーは自動 モードに入る。コントローラーのセットポイントは紙 切れ前のヘッドボックス灰分浱度から自動的に計算さ れる。秖切れ中は，この新しいコントローラーは紙の 灰分コントローラーの代わりに填料流量を変化させな がらヘッドボックスの灰分を安定した状態に保持する。 実際にヘッドボックスの灰分浱度が上がるにつれて，
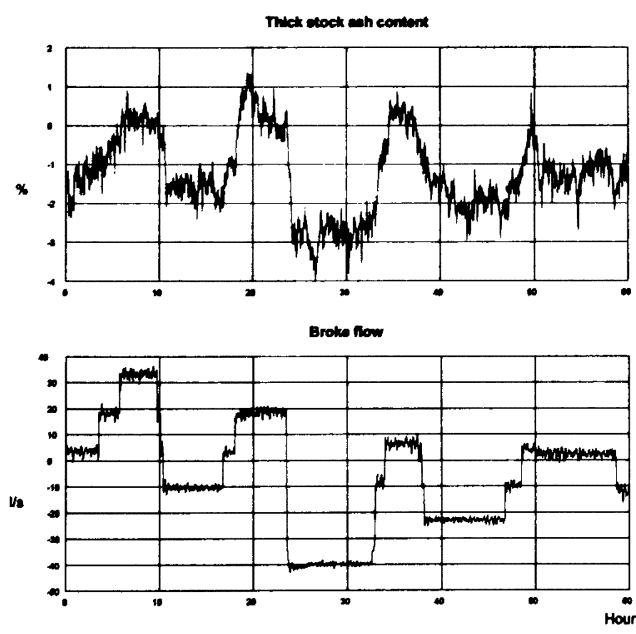

図 11 フローク流量と紙料の死分の変化
填料流量のセットポイントを下げていく。

紙切れが終わって，ある時間たつとコントローラー は自動的にマニュアルモードに戻り紙の灰分コントロ ールが自動モードに入る。この制御により紙の灰分は 紙切れ後も適正に保たれるため，復帰をすばやく行う ことができる。

\section{2 高濃度紙料のフィードフォワード制御}

ほとんどの抄紙機は，ブレンドチェスト後の高濃度 紙料の全濃度コントロールループを持っているだけで ある。一方, 高濃度灰分含有量は変動を制御されてな いうえ, 測定すらされていない。これは明らかにプロ セスの計装の弱点となっている。高濃度紙料の灰分は 変動しそして実際にショートサーキュレーションに 達し, 紙の灰分量に影響を与える外乱の重要な原因で ある。高浱度紙量の灰分変動の主な原因は, ブローク の品質と量の変化及びディスクフィルターの操業変動 である。完成紙料の全灰分の $60 \%$ 以上がディスク フィルターからくるという事実が忘れられている。こ のようにディスクフィルターの故障や期間変動が結果 としてウエットエンドに現れてくる。

ブレンドチェストとマシンチェストの濃度タンピン グ効果は，一般に考えられているほど大きくはない。
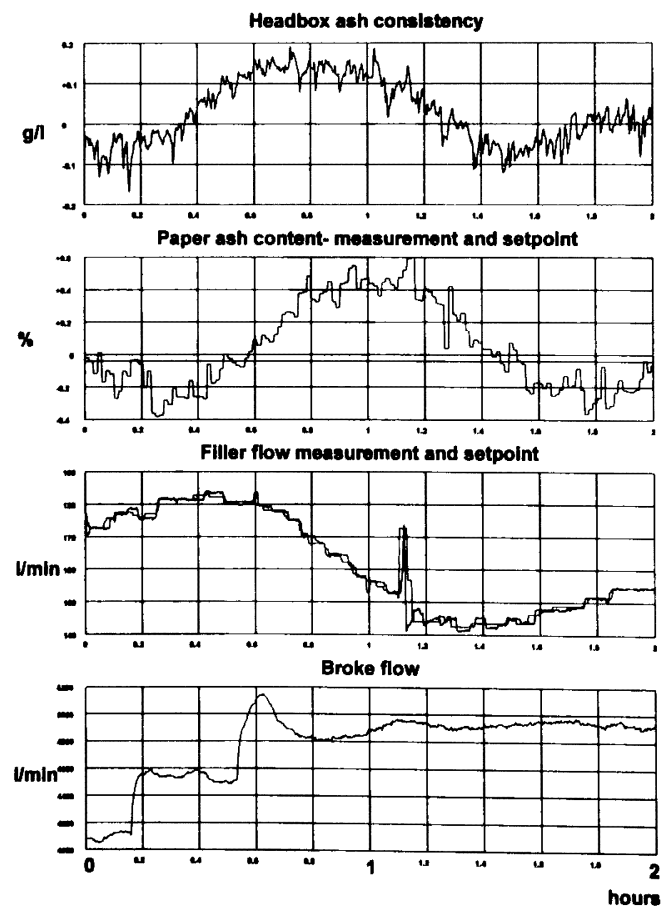

図 12 ブローク流量とヘッドボックスおよび完成紙 料の灰分量変化 
これは殊に年々生産量の増えている古い抄紙機ほど顕 著である。タンクのダンピング効果は時定数に依存し， 時定数はタンク容量とタンクを流れる流量によって決 まってくる。将来トレンドは, より高い生産スピード と，小さなタンクまたはタンクをなくす方において， オンライン測定と制御は非常に重要になるのみならず 絶対に必要となってきている。図 11 にブローク流量 の変動が高濃度紙料の灰分の変化となっている様子が 見られる。

紙料のコントローラーは，これら灰分の外乱を修正 はするが，しかしフィードバック制御と同じように， 紙に既にこの影響が現れた後でしかわからない。図 12 にブローク流量の変動がヘッドボックスと紙の灰 分濃度にいかに変化をもたらすかを示している。

これら高濃度紙料の灰分含有量の外乱は, 灰分含有 量を基にしたフィードフォワード制御によって飛躍的 に減じることができる。図13にこの制御の基本的な 原理を示す。

この制御の目的は完成紙料の灰分含有量の変動がへ

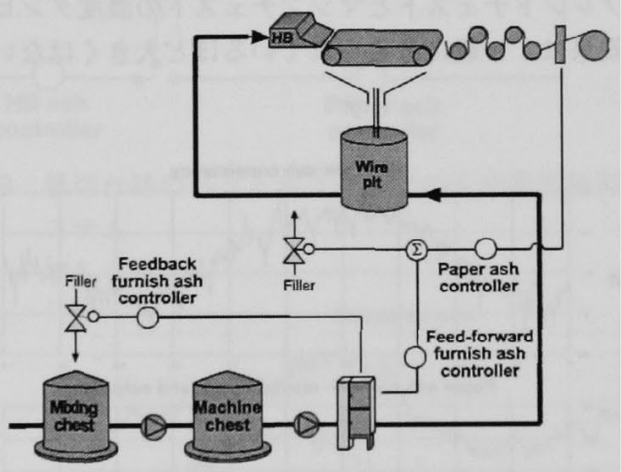

図 13 高濃度紙料の炏分制御

Fresh filler to wet end, I/s

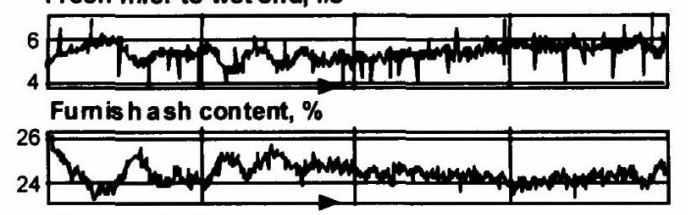

Paper ash, \%
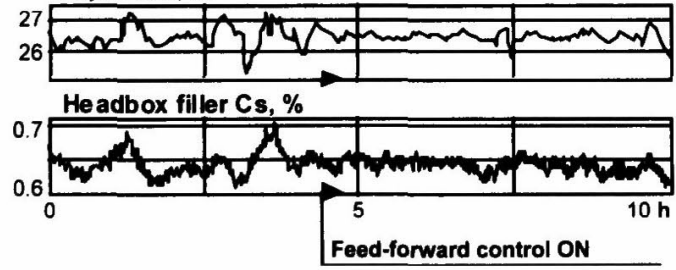

図 14 フィードフォワード制御と灰分含有量
ッドボックスと紙の灰分料の変動に達する前に補正を することである。図 14 に，この制御がヘッドボック ス濃度と紙の灰分量をいかに安定化するかを示してい る。この解法は, ヘッドボックスの濃度と灰分変動を 事前に対応して, 紙品質と抄紙機の操業性の改善を行 う手法である。

\section{5. 化学的コントロール}

\section{1 白水のカチオン要求量の自動制御}

制御システムは, 白水のカチオン要求量の測定とシ ョートサーキュレーション前の数個所で使用されるチ ヤージ制御のための薬剤が含まれている。このような 制御システムはカチオン要求量測定とコートブローク の投薬を基本とする，異なった投与場所への薬郕流量 制御のための '主”と ‘補助” のコントローラーで構 成されている。実際の制御システムは違う抄紙機に対 しては異なってくるし, 制御に利用する薬凨と, カチ オン要求量に及はす主な外乱の原因に依存してくる。

自動制御は，チャージレベルをセットポイントの士 5 ユニット以内に保持されている。図 15 に手動と自 動の一般的な例を示しており，自動は 20 時間後から 行われている。

自動のチャージ制御のメリットは, リテンション剂 のような薬剤にとって最適な安定した状態を作ること である。ウエットエンドが安定したチャージ状態であ れば，他の薬剤投与をより容易に最適化できる。さら にはマシーンオペレーターがチャージ測定を注視して， 薬剤量を調整する必要がなくなる。必要量の薬郕しか 使わない自動制御は, 薬剤の節約を達成することがで きる。

チャージ測定と制御は、ストーン表面门の固着の危 険をモニター可能で, 避けることができるためスター
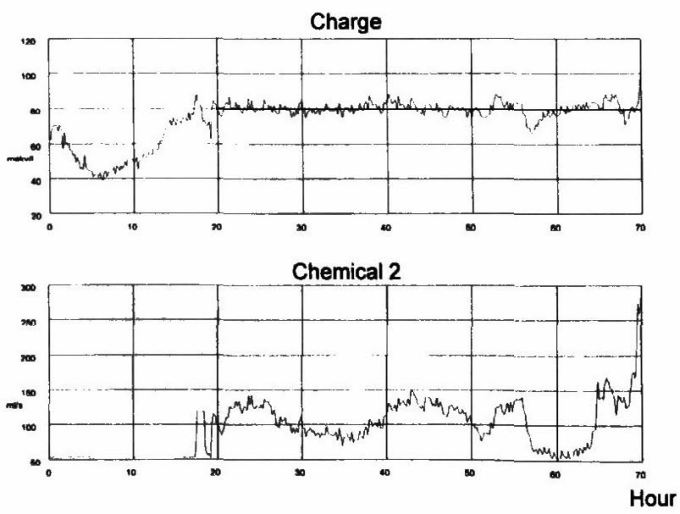

図 15 手動と自動カチオン要求量制御 


\section{トアップが容易になる。}

\section{2 漂度制御とカチオン要求量制御}

図 16 は, 濃度制御とカチオン要求量制御を自動に 入れたものである。この図から見られるように，それ ぞれの変数はセットポイントに非常に近いところに維 持されている。図には 2 回の品種変更が含まれてい て,2回ともセットポイントの変更が行われている。 この工場では主な品種毎にそれぞれ異なった最適な白 水謈度のセットポイントを設定している。薬剤流量が 変化するにつれて, 両コントロールともにチャージと 濃度を確実にセットポイントに保っている。両コント ロールともにどちらも相手がなしでは済まされず，相 互に依存している。

カチオン要求量制御は外乱を減らし，リテンション 剤の最適条件を用意することによって濃度制御を助け ている。カチオン要求量制御は図 17 に示すように, 単独では白水浱度を安定には保てない。このグラフで は, 白水制御が 0 時から 23 時までマニュアルでいる 間ずっと,カチオン要求量制御は自動制御に入ってい る。この間，白水浱度は安定していない。明らかに, 自動白水制御は白水浱度を安定に保つためには絶対に 必要である。

白水浱度制御とカチオン要求量の両者のコントロー
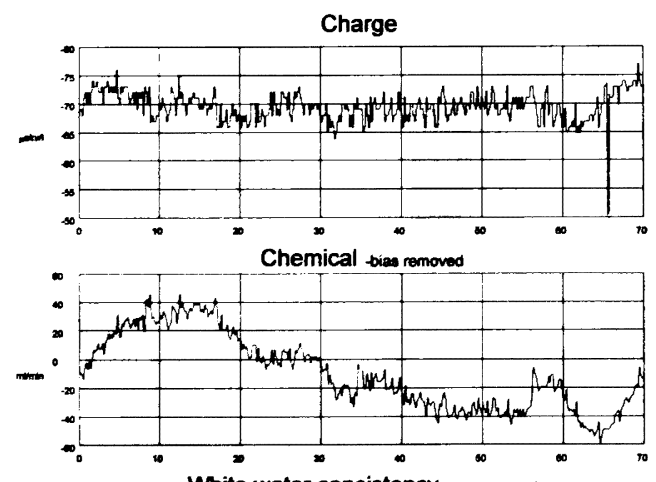

White water consistency-bies romoved
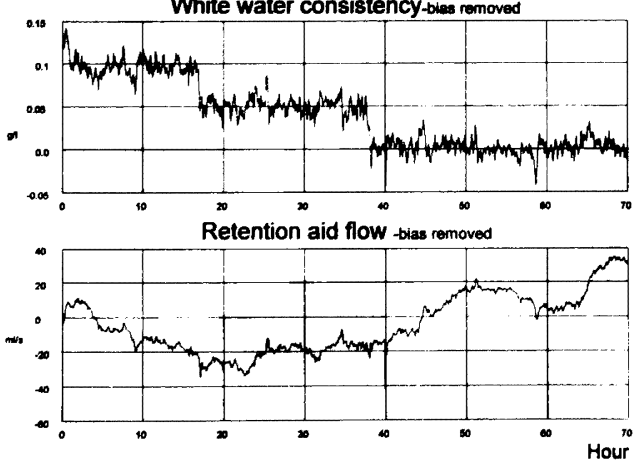

図 16 白水涱度制御とカチオン要求量
ルは，独立した手法としても効果的で有益である。し かしながら, カチオン要求量制御はそれ自身では白水 の濃度の安定性は補償しない。安定したリテンション を得るためには, 白水濃度制御が必要である。カチオ ン要求量は, 濃度制御がリテンション剤のプログラム のために最適な薬剤条件を作る手助けをする。コント ロールはお互いにサポートしあい，通常 2 種を連結し て使用する時に最善の結果が得られる。

これらのコントロールを用いると, チャージと濃度 の大きな, 突然の変動を避けることができ, 操業性を 改善する。

\section{6. 結 論}

新しいウエットエンドの管理コンセプト（WEM） は，重要なプロセス変数を測定し，制御することを基 にして開発された。我々は，完全に新しいウエットエ ンド管理システムを手にした。このシステムは少なく ともドライエンドの品質管理システムと同様な信頼性 と能力を有する測定が必要である。

WEM システムの重要な制御はリテンションとチャ ージ制御で，両者を有効に組み合わせた手法である。 チャージ制御は複数の長所を持つ。例えばリテンショ ン剤のような他の薬剤のために最適な安定した条件を
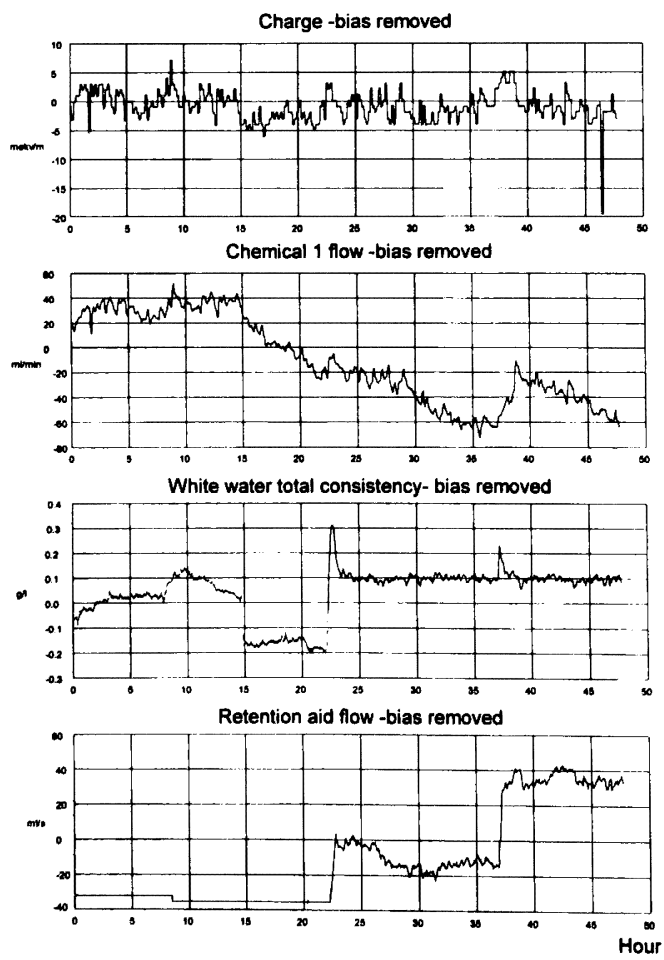

図 17 白水濃度制御と白水のカチオン要求量制御 
作り出す。白水濃度コントロールは, ワイヤリテンシ ョンのみならず, 全ショートサーキュレーション濃度 すら非常に効率的に安定化する。チャージ制御は白水 濃度制御の仕事を容易にし, 両者が併用して利用され るとき，これら 2 つの制御は理想的な白水濃度と最小 のリテンション刻の投与量でショートサーキュレーシ ヨンを安定化する強力なツールを提供する。結果とし て抄紙機の操業性, 効率と製品品質が顕著に改善され る。

本報文は，以下の方々による報文を基に作成したも のである。

Timo Rantala, Martti Artama, Jukka Nokelainen, Taina Sopenlehto : Valmet Automation Kajaani Inc. P.O.Box 177, Kajaani, Finland

\section{参考文献}

1) Pekkarinen Timo: New Approach to Wet End Management, XI Valmet Paper Technology Days, Jyvaskyla, Finland, 1998.

2) Antti Nissinen, Rantala Timo, Taisto Huhtelin. Jukka Nokelainen, Pentti Lautala: New Paper Machine Control Challenges with the Dilution Headbox-Part 1 : Consistency Control Solu- tions, 2 nd Ecopapertech Conference June 15, 1998, Helsinki

3) Rantala Timo, Antti Nissinen, Taisto Huhtelin, Jukka Nokelainen, Pentti Lautala : New Paper Machine Control Challenges with the Dilution Headbox-Part 2 : Consistency Control Solutions, 2 nd Ecopapertech Conference June 15, 1998, Helsinki

4) Scott, W.E. : Principles of Wet End Chemistry, Tappi Press, Atlanta, GA 1996

5) Lang D., Tian L., Kuusisto R., Rantala T., Multivariable Predictive Control For The Wet End ; paper was presented in PIRA conference Scientific and Technological Advances in the Measurement and Control of Papermaking, Edinburgh Nov. 9-10.1998, Scotland, p 9

6) PAMIRE-project: “Devalopment of measurement analytics and retention control in the paper machine wet end", End report; Ministry of Trade and Industry; RAINA-research programme, Report 4, Helsinki 1991 (Language Finnish, extended summary in English) 


\section{報 文 概 要 一 筧 \\ 電源の高信頼化・高品質化及び省エネルギーに適用される パワーエレクトロニクス装置の動向}

株式会社東芝 府中情報・社会システム社 パワーエレクトロニクス部 堺 高見，吉野 輝雄

紙パルフの工場・事業所を取り巻く電源環境はさまざまであるが, 生産性向上・製品品質向上のため には, 高信頼・高品質の電力供給が不可欠である。また, 環境保全の観点から, 省エネルギー施策が急 務とされている。さらに，生産管理のための，OA システムが普及しており，重大な情報を扱う装置へ の電源安定供給がますます必要になっている。

一方, 電力を扱う半導体素子, 光点弧サイリスタ・ゲートターンオフサイリスタ及び絶縁ゲートバイ ポーラトランジスタ（IGBT）の発展により, 高電圧・大電流を直接扱うことのできるパワーエレクト ロニクス装置が実用化されている。

パワーエレクトロニクス装置適用により，電源の信頼性向上と品質向上が期待できる。即ち，サイリ スタクリッパ・サイリスタリミッ夕を用いれば, 商用系統での事故発生時, 高速で系統連系を切り離し 可能なので，自家発系統側への影䇾を減じることができる。SPS（Stand-by Power System）は，瞬低 ・瞬停時に負荷に電力を供給し続ける。アクティブパワーフィルタは, 負荷の高調波電流成分を打ち消 し，電圧歪を改善する。

また，パワーエレクトロニクス装置は，省エネや環境保全に役立つ。太陽光発電には，直流を交流に 変換するインバータが必須である。負荷回生装置は, 従来使い捨てであった試験電力を, パワーエレク トロニクスにより電源にリサイクルする装置である。

装置だけではなくシステム解析技術が充実してきた。システム解析を行えば, 現状設備の問題点評価, バワーエレクトロニクス装置適用の事前評価を精度高く行うことができ，設備計画に有用である。

パワーエレクトロニクス装置は, 従来機器・装置では実現できなかった機能・性能を有しており，そ の逼用により訫パルプ工業の電力設備の信頼性・品質の向上, さらには, 製品生産効率向上に貢献する ものと期待される。

(本文 34 ページ)

\section{オンライン分析計によるウェットエンド管理とその制御法}

\section{ネレスオートメーション株式会社 大木 悟, 坂田 秀実}

抄紙機のウエットエンド化学を管理するため, われわれの目標はウエットエンド全体の操業に最大限

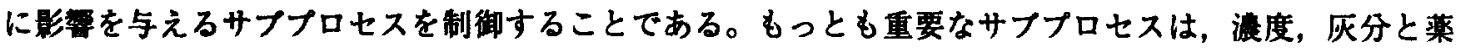
都である。

これら主な 3 種のグルーブの管理は，オンライン湘定と自動制御を基にして行う。この論文は, ウエッ トエンド管理ブラットフォームとなる，新しい分析計を紹介している。この新しい分析計はモデュール 棈造と，最新のソフトウエア技術を探用しており，新しい抄紙機のコンセプトに基づいている。 この制御コンセプトは, リテンション, 浱度, 灰分, チャージを制御してウエットエンドを安定化させ (30 80\%)，より均一な紙にして，より良い操業性をもたらすフィードバックとフィードフォワード制 御手法である。

（本文 43 ページ） 